the making of permanent preparations of fleas, mites and insects and the collection and examination of skin scrapings.

In a book of this quality it may appear ungracious to refer to any errors, of which there are remarkably few, but the description of Olsen's method for estimating the number of eggs of Fasciola hepatica per gram of sheep fæees requires correcting, also the host parasite list needs further revision to conform with all the changes in the new text.

This edition will, without doubt, enhance the reputation of Mönnig's book and both the author and the publishers are to be congratulated on their achievement. They have rejuvenated it, yet preserved all the excellent qualities of the original and provided a text-book which will be welcomed by all those interested in animal parasites.

$$
\text { F. ST. G. Suerth }
$$

\section{PLANT HUNTING IN EARLY AMERICA}

\section{Edward Palmer}

Plant Explorer of the American West. By Rogers McVaugh. Pp. xviii +430. (Norman, Oklahoma : University of Oklahoma Press, 1956.) 6 dollars.

\section{$\mathrm{D}$} R. EDWARD PALMER was born about 1831 in Norfolk and emigrated to America in 1849. He became famous during his lifetime as an explorer and botanist, and remains the most important early collector of botanical material in the southern United States and Mexico. His collecting career extended over more than fifty years. He made more than twenty thousand gatherings of plants, and sets of them were widely distributed in Europe as well as in America. Specimens found in herbaria to-day, however, are very frequently incompletely localized and without notes. Prof. McVaugh's book will enable these shortcomings to be remedied.

Palmer's career as an explorer began in 1854 when he sailed to South America with Captain Page on the Water Witch, visiting Argentina, Brazil and Paraguay. He next collected plants while on service as an Army surgeon during the Civil War in Colorado, on the frontier in Arizona (1865-67) and in the Indian Territory itself (1868). This must have been a difficult and daring activity, and the account of it makes exciting reading. After this, Palmer's reputation as a collector was established, and, from 1869 , he became a professional field-worker, mainly financing himself from the sale of specimens. He usually travelled alone to parts of the United States, branching off from the stage-lines by joining packtrains or riding with a mail-carrier as his guide. As civilization spread, he moved ahead: his earlier trips were to Colorado, Utah, Arizona and California with incursions into Lower Califormia; later he went to Mexico proper (notably with Parry in 1878) and Texas; after 1885 he concentrated more and more on Mexico and Lower California. $\mathrm{He}$ also visited Florida and the Bahamas (1874) and Cuba (1902). Palmer himself published at least thirty-five papers and many others are directly based upon his collections.

The mass of information in this book is very well arranged. The biographical account (120 pages) is followed by a geographical index (221 pages) in which are given elaborate details of Palmer's localities with local itineraries and dates. A summary of his journeys forms the first appendix and another comprises an annotated list of herbaria which include specimens collected by him. His field notes for Colorado (1861) and the Indian Territory (1868) are published in full. 'There is an extensive bibliography and an index to persons and institutions mentioned in the text. One of the most useful features of the book for non-American readers is the inclusion of footnotes on many of Palmer's contemporaries. On the other hand, such readers may wish the author had included a general map of Palmer's routes to supplement the biographical part of the text. Ideally, the geographical index includes precise references to an annotated list of modern maps. 'The twelve pages of illustrations include photographs of Palmer and of his handwriting.

Prof. McVaugh has produced a masterpiece of comprehensiveness; his fifteen years of work have resulted in an extraordinarily detailed summary of Palmer's botanical life. But not only this, he has written sensitively of the man as well as objectively of his work, and the book, which understandably has many of the characteristics of a catalogue, conveys also the human interest of the hero's unusual character. JoHN LEWIS

\section{SCIENCE AND DETECTION}

The Scientific Investigation of Crime By L. C. Nickolls. Pp. xiii +398 . (London : Butterworth and Co. (Publishers), Ltd., 1956.) 50s. net.

$T$ HIS book by the Director of the Police Laboratory, New Scotland Yard, gives an account of the work of the seven forensic science laboratories in England and Wales, describing, with many examples, the types of investigation undertaken and the equipment and methods employed. It reveals the great progress which has been made, since the firgt labor. atory of the kind was opened at Hendon in 1935, in the taking over by the police forces of the forensic scientific work formerly done by outside experts.

The scientific and technological work involved is, naturally, of great variety, and the methods range from the use of such weapons as X-ray diffraction, infra-red spectrometry and gas chromatography, to the making of plaster casts of footprints. All the subjects are dealt with adequately, and several, which are probably of the greatest general interest, including bloodstains, toxicology and identification of traces of biological material, are given especially thorough treatment. For example, the fifteen pages on wood fragments, with sixty-three excellent micrographs of sections of different timbers, each illustrating one or, at most, two characters of the Chatterton key card, are so good that they would be a most valuable acquisition, not only to all responsible for the identification of timbers, but also to every student of wood technology. Those pages and most of the remainder of the book, except Chapters 10 and 11, would be particularly useful to many educational establishments, research laboratories and individuals if they were made available as reprints. The subjects of those two chapters and, in particular, the unavoidably sordid examples given in Chapter 10, would appear to render the publication, as a whole, unsuitable for such general circulation.

The book is well produced, with good illustrations and a very full and useful bibliography at the end of each chapter.
H. I. Matthews 